\title{
HARGA YANG ADIL DALAM MEKANISME PASAR DAN PERAN PEMERINTAH DALAM PERSPEKTIF ISLAM
}

\author{
Mabarroh Azizah \\ Alma Ata Yogyakarta, mabarroh_hariz@yahoo.co.id
}

\begin{abstract}
Abstrak
This article focuses on the implementation of the just price in Islamic perspective, in which government intervention can be tolerated in this context. It is important therefore to be discussed what is the just price and also pricing theory in Islamic point of view. This article concludes that the just price is a fixed price, and it is also called as equal price. This price is resulted by a fair market, by a fair supply and demand. The participation of the state or government here will only be justified when instability arises, then the government should determine the price to maintain the interests of public as well as avoiding hoarding and injustices.
\end{abstract}

Key words: just price, market mechanism, government

\section{PENDAHULUAN}

Belanja erat terkait dengan mengkonsumsi, berbelanja menjadi kegiatan "awal" aktivitas sebelum kegiatan mengkonsumsi dilakukan. Berbelanja, pada akhirnya meghubungkan manusia dengan beberapa barang yang diproduksi dan menjadi komoditas pasar. Perspektif teori ekonomi menyatakan bahwa pasar adalah salah satu mekanisme yang bisa dijalankan oleh manusia untuk mengatasi probiem-problem ekonomi yang terdiri atas produksi, konsumsi, dan distribusi (Nasution, 2007). Oleh karena itu, komoditas merupakan produk yang bukan dihasilkan untuk konsumsi individu melainkan ada regulasi mekanisme pada penjualan di pasar.

Transaksi ekonomi pasar bekerja berdasarkan mekanisme harga agar dalam transaksi memberikan keadilan bagi seluruh pelakunya maka harga juga harus mencerminkan keadilan. Dalam pandangan Islam transaksi harus dilakukan secara sukarela ('antaradlim minkum) dan memberikan keuntungan yang proporsional bagi para pelakunya. Konsep harga yang adil telah dikenalkan oleh Rasulullah SAW, yang kemudian banyak menjadi bahasan dari para ulama di masa kemudian. Dalam situasi normal harga yang adil tercipta melalui mekanisme permintaan dan penawaran, dengan syarat mekanisme pasar dapat berjalan secara sempurna.

Seringkali harga pasar yang tercipta dianggap tidak sesuai dengan kebijakan dan keadaan perekonomian secara keseluruhan. Dalam dunia nyata mekanisme pasar terkadang juga tidak dapat berjalan dengan baik karena adanya berbagai faktor yang mendistorsinya (Nasution, 2007). Dalam perekonomian pasar bebas, sistem kekuatan permintaan dan penawaran dapat bergerak dengan leluasa dan bebas, harga yang terbentuk merupakan pencerminan keinginan masyarakat. Harga sebuah komoditas (barang dan jasa) ditentukan oleh penawaran dan permintaan, perubahan yang terjadi pada harga sangat ditentukan oleh terjadinya perubahan permintaan dan perubahan penawaran (Partediredja, 1999). Meskipun harga dan jumlah barang yang diperjualbelikan itu adalah akibat interaksi permintaan dan penawaran, ternyata di dalam prakteknya sukar sekali untuk mengukur permintaan dan penawaran tersebut, atau untuk meramalkan kemana harga dan jumlah itu akan bergerak.

Sementara itu kekuatan yang ada di belakang permintaan dan penawaran itu selalu berubah, penduduk selalu bertambah, harga barang-barang yang lain dan yang sedang kita 
analisis selalu naik turun dan pendapatan konșumen secara keseluruhan juga selalu berubah, yang kesemuanya juga pasti akan berimbas pada perubahan permintaan dan penawaran. Untuk itu, pemerintah memiliki peran yang besar dalam melakukan pengelolaan harga.

Menilik pada hadis Rasulullah SAW., yang diriwayatkan oleh Anas bin Malik bahwa sekali waktu terjadi kenaikan harga yang luar biasa di kota Madinah dan para sahabat meminta Nabi untuk menentukan harga, lalu Nabi bersabda Artinya, "Bahwa Allah adalah Dzat yang mencabut dan memberi sesuatu, Dzat yang memberi rezeki dan penentu harga..." (HR. Abu Daud). Menurut Ya'qub (2000), keadaan yang terjadi pada masa itu, rupanya sebagian besar kebutuhan penduduk kota Madinah dan sekitarnya, terutama bahan makanan didatangkan dari luar. Mahalnya barang-barang itu bukan karena permintaan para saudagar Madinah, tetapi pembelian dari luar sudah begitu tinggi.

Dari hal tersebut perlu digarisbawahi, bahwa pada saat kondisi market failure terjadi, satu hal yang perlu dipertimbangkan adalah apakah intervensi pemerintah perlu dilakukan atau tidak. Jika dengan intervensi justru akan membawa kepada kemungkinan terjadinya government failure yang justru akan menimbulkan 'kerusakan' lebih besar dibandingkan market failure (Nasution, 2007). Padahal harga yang adil merupakan harapan semua pihak.

Berdasarkan .lustrasi tersebut, tulisan ini mengkaji diskursus peranan kepentingan dari para pelaku pasar dan peranan pemerintah dalam mekanisme pasar untuk menuju bagaimanakah harga yang adil yang ingin di wujudkan dalam mekanisme pasar yang sesuai dengan tuntunan syariah guna menggapai hubungan muamalah yang baik yaitu hak eksklusif (adamy).

\section{MEKANISME PASAR DALAM KONSEP ISLAM}

Kemunculan budaya Islam memberikan konstribusi yag sangat besar kepada kemajuan pembangunan ekonomi dan teori ekonomi itu sendiri. Dan pasar adalah sebuah mekanisme yang dapat mempertemukan pihak penjual dan pembeli untuk melakukan transaksi atas barang dan jasa, baik dalam bentuk produksi maupun penentuan harga. Syarat utama terbentuknya pasar adanya pertemuan antara pihak penjual dan pembeli, baik dalam satu tempat ataupun yang berbeda.

Menurut Marthon (2004), dalam konsep ekonomi Islam, pasar yang ada berdasarkan atas etika dan nilai-nilai syari'ah, bajk dalam bentuk perintah, larangan, anjuran, ataupun himbauan. Pelaku pasar mempunyai tujuan utama dalam melaksanakan sebuah transaksi, yaitu mencari ridha Allah demi mewujudkan kemaslahatan hidup bersama di samping juga untuk mewujudkan kesejahteraan individu.

Wujud suatu pasar dalam Islam, merupakan refleksi dan kemampuan masyarakat dalam memenuhi kebutuhan-kebutuhannya, dan bukan sebaliknya. Islam mengatur bagaimana keberadaan suatu pasar tidak merugikan antara satu dengan yang lain. Oleh karena itu, keterlibatan produsen, konsumen, dan pemerintah di pasar sangatlah diperlukan dengan tujuan untuk menyamakan persepsinya tentang keberadaan suatu harga. Bila hal itu tercapai maka mekanisme pasar yang sesuai dengan syari'at Islam akan berdampak pada kesejahteraan masyarakat (Sudarsono, 2003).

Oleh sebab itu, penting sekali bagi umat Islam untuk secara kumulatif memberikan dukungannya kepada ide-ide pemberdayaan, kemajuan, dan pencerahan peradaban bisnis dan perdagangan. Islam secara ketä mendorong umatnya untuk giat dalam aktivitas keuangan dan usaha-usaha yang meningkatkan kesejahteraan ekonomi dan sosial. Konsep Islam menegaskan bahwa pasar harus berdiri di atas prinsip persaingan bebas (perfect competition) 
yang dalam hal ini bukan berarti kebebasan harus berlaku mutlak, akan tetapi kebebasan yang dibungkus frame aturan syariah (Nasution, 2007).

Konsep di atas menentukan bahwa pasar yang sesuai aturan Islam harus bisa menjamin adanya kebebasan pada keluar masuknya sebuah komoditas di pasar beserta perangkat dan faktor-faktor produksinya. Hal ini dimaksudkan untuk menjamin adanya pendistribusian kekuatan ekonomi dalam sebuah mekanisme yang proporsional. Otoritas pasar tidak bisa membatasi elemen pasar pada peran industri tertentu atau sejumlah industri tertentu, karena hal ini hanya akan membawa kepada adanya perilaku monopolistik yang berada pada kondisi produktivitas sebuah industri sehingga bisa dibatasi untuk kepentingan kenaikan harga ataupun lainnya.

Jika pasar bisa mangakomodasi berbagai bentuk kebebasan yang ada, hal tersebut berarti pasar mempunyai arti keterlibatan peran sebagai instrumen terstruktur untuk sebuah pendistribusian barang dan jasa, efsisiensi produksi dan distribusi income. Lebih jauh Nasution, (2007) menjelaskan dari ketiga peran pasar tersebut, yaitu:

\section{Peran Pasar Dalam Distribusi Barang dan Jasa}

Suatu kebebasan akan mengarahkan pasar pada distribusi barang dan jasa secara optimal kepada keseluruhan konsumen, selama daya beli (purchasing power) antar para konsumen di pasar tidak terpaut berjauhan satu sama lainnya. Dengan begitu sistem Islam mengarahkan kepada distribusi kekayaan yang adil dan ihsan, sehingga sebuah komunitas muslim tidak terkotak-kotak dengan jenjang level kekayaan yang terpaut berjauhan antara satu jenjang dengan yang lainnya. Komunitas Islam harus dibentuk dalam satu kesatuan "madani" yang menjunjung persaudaraan sesama muslim. Hal inilah kemudian yang menegaskan hikmah disyariatkannya instrumen zakat dan batasan-batasan syariah dalam mencari rezeki.

Distribusi pendapatan atau pembagian kekayaan akan menjamin terjadinya keadilan distribusi barang dan jasa di pasar, sebab dalam pasar terbuka dan persaingan sempurna setiap individu akan selalu berpikir dan berusaha untuk mendapatkan manfaat atau utilitas tertinggi dari setiap perencanaan anggaran pengeluarannya. Dari situ bisa dipastikan akan rusak apabila sistem monopolistik diterapkan di pasar, di mana para konsumen tidak mempunyai daya beli yang selevel antara satu dengan yang lainnya. Hal ini telah disinyalir oleh Ibnu Taimiyah bahwa "penjual dilarang dengan sengaja untuk tidak menjual sesuatu kecuali dengan harga yang telah mereka tentukan sendiri".

\section{Peran Pasar dalam Efisiensi Produksi}

Kontrol dan pembatasan beberapa faktor produksi dalam tatanan nilai Islam dengan memanfaatkan intsrumen harga pasar. Dalam hal ini instrument harga akan diarahkan pada efisiensi bahan baku dari produksi dari berbagai macam hasil produksi permintaan konsumen di pasar. Konsep ini menegaskan bahwa setiap harga produk yang dibayarkan oleh konsumen mewakili atau mengkover besar ongkos produksi yang diperlukan.

Dengan demikian, keputusan para produsen dan investor dalam memproduksi barang dan jasa akan selalu dikaitkan dan bergantung pada expected return (prediksi keuntungan) yang akan didapat. Disebabkan kenaikan harga produk ditentukan oleh volume permintaan pasar, yang secara otomatis akan merangsang para produsen untuk menambah jumlah produknya'di pasar. Sementara di sisi lain, jika terjadi penurunan harga, para produsen akan dengan serta merta mengurangi jatah produksinya, baik dalam kuantitas maupun kualitas, yang dalam hal ini akan mengubah bahan baku produk kepada kualitas yang lebih rendah. 
3. Peran Pasar dalam Distribusi Pendapatan .

Hukum permintaan dan penawaran di pasar sangat berperan dalam menentukan pendapatan. Hal'ini karena pendapatan di pasar direpresentasikan oleh harga ( $p r i c e$ ) yang berlaku sebagai alat tukar atas penggunaan jasa ataupun aneka ragam produk. Konsep distribusi kemudian memanfaatkan instrumen, harga untuk menentukan nilai barang maupun jasa yang ditawarkan di pasar. Dengan demikian setiap pendapatan yang diterima berlaku sebagai insentif dari kepemilikan beberapa faktor produksi.

Sementara itu, Marthon (2004) menyatakan bahwa untuk menjaga hak-hak pelaku pasar yaitu penjual dan pembeli dalam menghindari transaksi yang menyebabkan distorsi dalam pasar serta mendorong untuk mewujudkan kemaslahatan individu maupun masyarakat, dibutuhkan suatu aturan dan kaidah-kaidah umum yang dapat dijadikan sebagai sandaran. Aturan dan kaidah-kaidah itu adalah sebagai meliputi:

a. Adil dalam takaran dan timbangan. Konsep keadilan harus diterapkan dalam mekanisme pasar.

b. Larangan mengkonsumsi riba.

c. Kejujuran dalam transaksi.

d. Larangan bai'najasy, yaitu transaksi jual beli di mana si penjual menyuruh orang lain memuji barangnya atau menawar dengan harga tinggi agar orang lain tertarik untuk membelinya, sementara si penawar sendiri tidak bermaksud untuk benar-benar membeli barang tersebut.

e. Larangan talaghi al-wafidain, yaitu menjemput penjual atas barang dagangannya di luar kota, sebelum penjual tersebut sampai pada pasar.

f. Larangan menjual barang yang belum sempurna kepemilikannya, karena dalam ekonomi Islam proses transaksi jual beli suatu barang harus sempurna kepemilikannya. Dalam arti, seseorang tidak boleh menjual suatu barang yang belum penuh kepemilikannya dan masih dalam keterlibatan pihak lain.

g. Larangan ikhtikar, yaitu menahan atau menimbun komoditas kebutuhan masyarakat untuk dijual dengan tujuan menaikkan harga.

h. Konsep kemudahan dan kerelaan dalam pasar. Kesepakatan dan kerelaan merupakan fondasi dasar dalam melakukan transaksi.

Dalam pembahasaan di atas, dapat digambarkan bahwasannya ekonomi Islam mengayomi kebebasan pasar untuk berfungsi sebagai penentu nilai produk-produk perekonomian. Dan kebebasan yang dimaksud bukanlah kebebasan yang berlaku mutlak namur kebebasan pasar harus pula menyesuaikan dengan prinsip-prinsip yang digariskan ajaran Islam dalam kerja produktif dan keberagamannya.

\section{KONSEP HARGA YANG ADIL}

Konsep tentang harga yang adil (justum pretium) mula-mula dilaksanakan di Roma, dengan latar belakang pentingnya menempatkan aturan khusus untuk memberi petunjuk dalam kasus-kasus yang dihadapi hakim, di mana dengan tatanan itu dia menempatkan nilai dan sebuah barang dagangan atau jasa. Sementara dalam konsep Yunani tentang harga yang adil, adalah ketika penduduk memperoleh sesuatu dan pertukaran yang benar-benar seperti yang mereka miliki sejak awal, tidak kurang dan tidak lebih. Mereka menyatakan bahwa hal tersebut menjadi milik mereka, tak ada yang dirugikan atau diuntungkan. Dengan demikian dapat dikatakan bahwa pada masa tersebut konsepsi maupun doktrin tentang harga lebih banyak berpjjak pada basis etika ketimbang ekonomi (Islahi, 1997). 
Sedangkan dalam konsep ekonomi Islam, menurut Sudarsono (2003), harga dibentuk oleh keseimbangan permintaan dan penawaran. Keseimbangan tersebut tidak terjadi bila antara penjual dan pembeli tidak bersikap saling merelakan. Kerelaan ini ditentukan oleh penjual dan pembeli dalam mempertahankan kepentingannya atas barang tersebut. Jadi, harga ditentukan oleh kemampuan penjual untuk menyediakan barang yang ditawarkan kepada pembeli, dan kemampuan pembeli untuk mendapatkan barang tersebut dari penjual.

Konsep Islam memahami bahwa pasar dapat berperan efektif dalam kehidupan ekonomi bila prinsip persaingan bebas dapat berlaku secara efektif. Pasar tidak mengharapkan adanya intervensi dari pihak manapun, tak terkecuali Negara dengan otoritas penentuan harga atau privat sektor dengan kegiatan monopolistik ataupun yang lainnya. Oleh karena itu Sudarsono (2003), menuturkan bahwa keseimbangan pasar dalam Islam mempertimbangkan beberapa hal, di antaranya adalah:

1. Kondisi pasar yang kompetitif mendorong segala sesuatunya menjadi terbuka. Dengan sama-sama merelakan keadaan masing-masing diketahui orang lain, berarti produsen dan konsumen mengetahui langsung kelebihan dan kelemahan dari barang yang ada di pasar, sehingga menjadikan semua pihak mendapatkan kepuasan. Bila produsen menjual produknya tidak terbuka maka masyarakat akan cenderung merasa kurang puas, maka ia akan memilih produsen lain.

2. Produsen dilarang melakukan praktek perdagangan demi keuntungan pribadi dengan cara memberhentikan pedagang di pinggir jalan sebelum mengetahui harga yang berlaku di pasaran.

3. Monopoli dan oligopoli tidak dilarang keberadaannya selama mereka tidak mengambil keuntungan di atas keuntungan normal.

4. Islam melarang penimbunan karena alasan untuk mencari keuntungan dari kelangkaan barang di pasar.

5. Islam melarang untuk bertindak curang. Bila terhadap timbangan, ukuran, jenis dan nilai barang dikurangi maka pengaruhnya terhadap pembeli adalah daya beli pembeli berkurang, dan akan meningkatkan nilai jual barang.

6. Islam melarang menyembunyikan cacat barang demi untuk mendapatkan harga yang tinggi.

Selanjutnya tentang harga yang adil lbnu Taimiyah (dalam Matrani, 2008) mendefenisikan bahwa harga yang setara itu adalah harga baku, di mana penduduk menjual barang-barang mereka dan secara umum diterima sebagai sesuatu yang setara dengan itu dan untuk barang yang sama pada waktu dan tempat yang khusus. Harga setara itu adalah sesuai dengan keinginan atau lebih persisnya harga yang ditetapkan oleh kekuatan pasar yang berjalan secara bebas antara penawaran dan permintaan. Begitu juga sasaran utama dan harga yang adil dan gagașan lain yang berkaitan dengannya adalah memelihara keadilan dalam transaksi timbal balik dan hubungan-hubungan lain di antara anggota masyarakat.

Dalam konsep Islam penentuan harga dilakukan oleh kekuatan pasar yaitu kekuatan permintaan dan penawaran. Pertemuan permintaan dengan penawaran tersebut haruslah terjadi secara rela sama rela, tidak ada pihak merasa terpaksa untuk melakukan transaksi pada suatu tingkat harga, sebagaimana firman Allah SWT.

"Hai orang-orang yang beriman, janganlah kamu saling mamakan harta sesamamu dengan jalan yang batil, kecuali dengan jalan perniagaan yang berlaku dengan suka sama suka di antara kamu. dan janganlah kamu membunuh dirimu; Sesungguhnya Allah adalah Maha Penyayang kepadamu" (QS:4:29) 
Di sisi lain, Karim (2002) menambahkan dalam hal harga para ahli fiqih merumuskannya sebagai the price of equivalen (harga padan). Konsep harga padan ini mempunyai implikasi penting dalam ilmu ekonomi, yaitu keadaan pasar yang kompetitif. Dalam konsep ini, monopoli atau oligopoli dalam artian hanya penjual atau beberapa penjual tidak dilarang keberadaannya, selama mereka tidak mengambil keuntungan di atas keuntungan normal.

Adanya suatu harga yang adil telah menjadi pegangan yang mendasar daiam transaksi yang Islami. Pada prinsipnya transaksi bisnis harus dilakukan pada harga yang adil, sebab ia adalah cerminan dari komitmen syariah Islam terhadap keadilan yang menyeluruh. Secara umum harga yang adil ini adalah harga yang tidak menimbulkan eksploitasi atau penindasan (kedzaliman) sehingga merugikan salah satu pihak dan menguntungan pihak yang lain. Harga harus mencerminkan manfaat bagi pembeli dan penjualannya secara adil, yaitu penjual memperoleh keuntungan yang normal dan pembeli memperoleh manfaat yang setara dengan harga yang dibayarkannya (Islahi, 1997).

\section{INTERVENSI PEMERINTAH DALAM REGULASI HARGA}

Konsep ajaran Islam secara keseluruhan menjunjung tinggi mekanisme pasar yang bebas. Harga keseimbangan dalam pasar yang bebas (competetive market price) merupakan harga yang paling baik, sebab mencerminkan kerelaan antara produsen dan konsumen dalam arti bisa memenuhi persyaratan antaraddim min kum. Meskipun demikian, terkadang harga yang seimbang tersebut tidak sesuai dengan kepentingan masyarakat secara keseluruhan, baik karena tingkat harga tersebut terlalu tinggi atau rendah, atau juga karena proses pembentukan harga tersebut tidak wajar. Dalam dunia nyata, mekanisme pasar juga seringkali tidak berjalan dengan baik. Dalam keadaan seperti tersebut perlukah intervensi pemerintah ke dalam pasar agar harga menuju pada posisi yang diinginkan?

Chapra (2001) berpendapat terkait dengan perlu tidaknya intervensi pemeritah dalam dunia perdagangan yang terlihat dalam persaingan pasar dan diikuti regulasi harga memanglah sangat penting. Kendati harapan tersebut ternyata belum memadai. Sebagian besarulama Islam menekankan perlunya peran nilai-nilai moral bagi semua pelaku bisnis di dalam pasar, guna meraih kebersihan jiwa dan kejujuran. Sebab tidak seluruh individu sadar dengan tugasnya, andai pun sadar dan mengetahui mereka pun belum semuanya mau melaksanakannya.

Dalam mekanisme pasar, regulasi harga dan moral harus ada dalam satu kesatuan paket pemikiran, sebab apabila hanya terwujudkan nilai moral dan harga saja, boleh jadi belum mampu mewujudkan tujuan-tujuan yang diinginkan masyarakat. Oleh karena itu peran efektif Negara sebagai mitra, katalisator, dan fasilitator sangat dibutuhkan untuk mewujudkan misi Islam. Ada beberapa hadis telah menekankan perlunya peran-peran tersebut. Salah satu hadisnya adalah Barangsiapa telah mendapatkan dari masyarakat tetapi tidak dapat menjalankannya dengan keikhlasan, maka dia tidak pernah mencium harumnya surga (HR. Bukhari). Dalam hadis lain beliau juga bersabda Allah lebih banyak mengendalikan melalui penguasa daripada apa yang la kendalikan melalui AI-Quran (Nasution, 2007).

Perhatian pada pentingnya peranan Negara telah dicerminkan oleh tulisan para ulama terkemuka sepanjang sejarah. Al-Mawardi (dalam Nu'man, 1985) misalnya, telah menyatakan bahwa keberadaan sebuah pemerintah yang efektif sangat diperlukan untuk mencegah kadzaliman dan pelanggaran. Sementara itu, Ibnu Taimiyah menekankan Islam dan Negara mempunyai hubungan yang tidak dapat dipisahkan. Sebagaimana juga dikutip Islahi (1988), kebijakan intervensi harga menurut Ibnu Taimiyah terbagi menjadi dua, yaitu: 
1. Intervensi harga yang zalim dan tidak sah

Intervensi harga dipandang sebagai zalim dan tidak sah apabila kebijakan tersebut menyebabkan kerugian atau penindasan kepada para pelaku pasar. Jika harga ditetapkan di atas harga pasar maka tentu akan merugikan konsumen, sementara jika ditetapkan di bawah harga pasar tentu akan merugikan produsen.

2. Intervensi harga yang adil dan sah

Intervensi harga dipandang adil jika kebijakan ini tidak menimbulkan kerugian atau penindasan kepada para pelaku pasar. Untuk itu intervensi harga yang adil justru akan membawa tingkat harga kepada posisi harga pasar yang seharusnya atau harga yang wajar. Dalam posisi ini baik penjual maupun pembeli tidak dirugikan.

Dari situ intervensi pasar juga tidak selalu diartikan hanya mempengaruhi permintaan dan penawaran saja, tetapi hal-hal yang dapat memperlancar penawaran dan permintaan. Ibnu Khaldun telah berkata: "Ketika barang-barang yang tersedia sedikit maka harga-harga akan naik. Tetapi, bila jarak antar kota dekat dan aman untuk melakukan perjalanan, maka akan banyak barang yang diimpor sehingga ketersediaan barang-barang akan melimpah dan harga-harga akan turun". Terganggunya transportasi akan menghambat pasokan barang dan jasa di pasar sehingga mengurangi penawaran. Pemerintah harus memperbaiki hambatan transportasi ini agar lancar kembali sehingga penawaran barang di pasar akan normal kembali.

Dan proses implementasi syariah tidak akan mungkin tanpa adanya Negara yang memainkan peranan, dan Negara mungkin akan terpuruk dalam pemerintahan yang tidak adil dan tirani tanpa pengaruh syariah. Demikian pula Baqir al-Sadr (dalam Chapra, 2000) mengatakan bahwa intervensi pemerintah dalam ruang lingkup kehidupan berekonomi adalah penting dalam menjamin keselarasan dengan norma-norma Islam. yaitu ;

Secara lebih rinci, Mannan (2001) menunjukkan 3 fungsi dasar dari regulasi harga,

1. Harus menunjukkan fungsi ekonomi yang berhubungan dengan peningkatan produktifitas dan peningkatan pendapatan masyarakat miskin melalui alokasi dan realokasi sumber daya ekonomi.

2. Harus menunjukkan fungsi sosial dalam memelihara keseimbangan sosial antara masyarakat kaya dan miskin.

3. Harus menunjukkan fungsi moral dalam menegakkan nilai-nilai syariah Islam, khususnya yang berkaitan dalam transaksi ekonomi misalnya kejujuran, keadilan, dan kemanfaatan (mutual goodwill).

Sedangkan konsep Islam dalam model kebijakan regulasi harga Mannan (2001) mengkategorikan pada dua hal, yaitu: (1) jenis penyebab perubahan harga tersebut, dan (2) urgensi harga terhadap kebutuhan masyarakat, yaitu keadaan darurat. Secara garis besar penyebab perubahan harga dapat juga dibagi menjadi dua, yaitu:

1. Genuine' factors, yaitu faktor-faktor yang bersifat alamiah. Kebijakan yang ditempuh untuk stabilisasi harga adalah dengan intervensi pasar (market intervention) dengan mempengaruhi posisi permintaan dan atau penawaran sehingga tercipta harga yang lebih pas.

2. Non genuine factor, yaitu faktor-faktor yang menyebabkan distorsi terhadap mekanisme pasar yang bebas. Kebijakan yang ditempuh untuk stabilisasi harga adalah dengan menghilangkan penyebab distorsi tersebut sehingga mekanisme pasar yang bebas dapat bekerja kembali, termasuk dengan cara penetapan harga (price intervention) 
Intervensi pasar juga dapat dilakukan manakala pemerintah menemukan bukti bahwa para pedagang banyak menahan barang-barangnya. Bahkan, demi kemaslahatan bersama, pemerintah dapat memaksa pedagang-pedagang tersebut untuk menjual barang-barangnya sehingga pasar akan kembali beroperasi dengan bebas (Sofyan, 2001). Pemerintah dapat menggunakan dana negara (dari Baitul Maal) untuk membiayai. intervensi pasar. Namun, jika dana Baitul Maal tidak memadai maka pemerintah dapat meminta bantuan pendanaan dari masyarakat golongan kaya (an-Nabhani, 2000). Terdapat dua alasan untuk hal ini. Pertama, karena pihak yang menderita kerugian paling parah akibat kenaikan harga biasanya adalah masyarakat golongan miskin, maka golongan kaya wajib membantu masalah ini. Bantuan golongan kaya ini termasuk dalam pengeluaran fii sabilillah. Kedua, pemerintah berkewajiban memelihara kesejahteraan masyarakatnya, terutama golongan miskin.

\section{PENERAPAN HARGA ADIL YANG ISLAMI}

Agar mekanisme pasar dapat berperan secara normal (alamiah) dan terjamin keberlangsungannya, di mana struktur dan mekanismenya dapat terhindar dari perilaku negatif para pelaku pasar, maka dalam ajaran Islam banyak sekali dijumpai stimulan ataupun insentif (reward) untuk pahala di akhirat bagi para pelaku pasar, yang dapat menerapkan bisnisnya secara halal. Hal ini tentu dilengkapi dengan perangkat tata laku dagang yang berproses kepada akhlak kejujuran, amanat, dan toleransi untuk tidak melakukan praktek-praktek negatif yang berdampak kepada distorsi mekanisme pasar.

Konsep halal dan haram sangatlah jelas untuk ikut mewarnai aspek hukum dalam mekanisme transaksi bisnis di pasar. Secara umum aturan halal dan haram kontrak komersial atau bisnis diatur dalam firman Allah SWT:

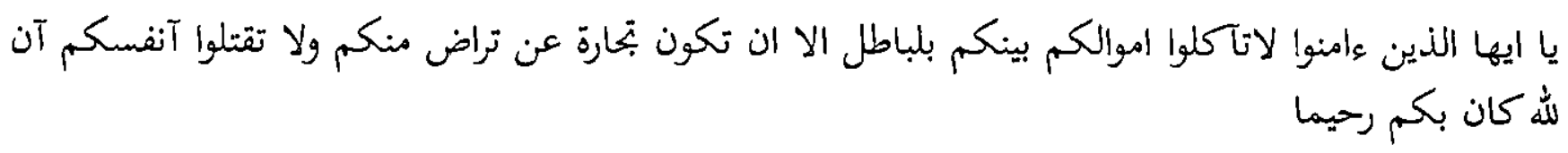

"Hai orang-orang yang beriman, janganlah kamu saling memakan harta sesamamu dengan jalan yang batil, kecuali dengan jalan perniagaan yang berlaku dengan suka sama suka di antara kamu...." (QS. An-Nisaa' (4) ayat 29).

Mekanisme suka sama suka adalah panduan dan garis al-Quran dalam melakukan kontrol terhadap perniagaan yang dilakukan. Teknik sistem dan aturan main tentang tercapainya tujuan ayat tersebut menjadi ruang ijtihad bagi pakar muslim dalam menerjemahkan konsep dan implementasinya terhadap konteks pasar modern saat ini.

Sebab persaingan dalam pasar seringkali berjalan tidak sehat, tidak fair, sehingga harga yang terjadipun tidak mencerminkan competition market price. Richard (1983) menyebut beberapa praktek hal tersebut, antara lain:

1. Demi meraih keuntungan yang tinggi seringkali penjual melakukan berbagai cara untuk bisa menjual pada hargä yang tinggi. Manipulasi terhadap informasi yang benar seringkali dilakukan oleh produsen, sehingga ekspektasi konsumen terhadap barang yang dibelinya menjadi salah. Inilah yang disebut tadlis, yaitu penipuan. Para pembeli dalam kasus ini sesungguhnya terpaksa harus membayar dengan harga yang lebih tinggi dari yang sewajarnya. Tadlis dapat terjadi dalam hal kualitas (barang bermutu rendah dikatakan bermutu tinggi), kuantitas (ukuran atau takaran yang tidak tepat) atau harga (barang murah dijual dengan mahal). 
2. Harga yang tinggi ini dapat diambil antara lain karena memanfaatkan ketidaktahuan/ kebodohan konsumen terhadap barang yang dijual (ghaban faa hisy). Kebodohan konsumen sengaja dimanfaatkan untuk menaikkan harga sehingga harga yang terjadi tentu tidak akan mencerminkan keuntungan riil keduanya.

3. Cara lain adalah dengan melakukan kolusi antara penjual dan sekelompok pembeli tertentu (yang sebenarnya kolega penjual) untuk menipu harga pasar. Misalnya konsumen tertentu ini membeli dengan harga tinggi sehingga konsumen lainnya terpaksa juga membeli dengan harga tinggi pula.

4. Sementara untuk memenangkan persaingan dengan pelaku lain juga terdapat penjual yang menawarkan barangnya dengan harga di bawah pasar. Dalam pasar yang kompetetif, sebagaimana kondisi pasar pada masyarakat Islam klasik, menjual di bawah harga pasar merupakan predatory market. Dengan menjual di bawah harga pasar, meskipun harus merugi, para penjual ini berharap pesaingnya akan keluar darj pasar, dan setelah itu mereka bisa kembali menaikkan harga untuk mendapatkan keuntungan di atas keuntungan normal. Dalam situasi seperti ini para penjual yang memiliki modal besar kemungkinan mampu bertahan, tetapi yang bermodal kecil terpaksa keluar dari pasar.

Dalam kenyataan seringkali juga terjadj penjual menawarkan barang dagangan dengan harga yang terlalu tinggi, sementara konsumen menginginkan terlalu rendah. Jika proses tawar-menawar di antara keduanya tidak dapat terjadi, maka dapat dipastikan mekanisme pasar akan terganggu. Oleh karena itu, menurut Mufraini (2006), pemerintah harus juga menetapkan harga yang dapat menguntungkan kedua belah pihak, yaitu harga yang. lazim (customary price).

Jumhur ulama juga sepakat bahwa kondisi darurat (emergency) dapat menjadi alasan pemerintah mengambil kebijakan intervensi harga, tetapi tetap berpijak kepada keadilan. Secara umum kondisi darurat yang dimaksud adalah: (Frank, 2003)

1. Harga naik sedemikian tinggi di luar kewajaran sehingga tidak terjangkau masyarakat.

2. Menyangkut barang-barang yang amat dibutuhkan oleh masyarakat, misalnya bahan pangan.

3. Terjadi ketidakadilan atau eksploitasi antara pelaku-pelaku dalam transaksi tersebut.

Maka dari itu kemudian para ulama menyimpulkan satu konsep fighiyah yang berhubungan dalam penerapan harga pada regulasi mekanisme pasar, yang menegaskan atas pelarangan bagi para pelaku pasar untuk mempraktekkan sejumlah transaksi berikut: (Siddiqi, 1988)

1. Transaksi riba, gharar, dan maysir

Dalam perspektif para sarjana muslim kontemporer infrastruktur perekonomian Islam harus berdiri di atas perekonomian tanpa bunga. Oleh karena, transaksi yang di jalankan dalam kerja dan bisnis (kontrak/akad) mengacu kepada konsep-konsep fiqh mu'amalah yang sudah dikonvergensi dengan sistem ekonomi dan keuangan modern. Subtansi dari pelarangan riba adalah untuk mengantisipasi adanya tindakan-tindakan eksploitasi terhadap mereka yang lebih lemah dalam mekanisme kerja dan bisnis.

2. Transaksi an-Najsy

Yaitu adanya kesepakatan antara penjual dan pihak ketiga untuk melakukan penawaran palsu sehingga dapat mempengaruhi perilaku calon pembeli yang sebenarnya.

3. Transaksi al-Ghaban

Adalah suatu transaksi jual beli yang dilakukan di bawah atau di atas harga yang sebenarnya. 
Dalam transaksi jenis ini sangat terbuka lebar terjadinya asimetris information antara pelaku pasar. Sehingga penentuan harga melalui mekanisme pasar haruslah berdasarkan prediksi kondisi keuangan riil dari perusahaan tersebut.

4. Transaksi al-Ma'dum:

Yaitu jenis penjualan barang dan jasa yang tidak atau belum dimiliki langsung oleh si penjual.

\section{KESIMPULAN}

Berbuat adil adalah suatu keharusan apalagi dalam kaitannya dengan harga. Harga adalah nillai sesuatu barang yang ditentukan atau diterapkan dengan uang. Harga yang adil (just price) atau harga setara dalam Islam adalah harga baku, di mana penduduk menjual barang-barang mereka dan secara umum diterima sebagai sesuatu yang setara dengan itu dan untuk barang yang sama pada waktu dan tempat yang khusus. Harga setara itu adalah sesuai dengan keinginan atau lebih persisnya harga yang ditetapkan oleh kekuatan pasar yang berjalan secara bebas antara penawaran dan permintaan.

Sepanjang sejarah, umumnya harga ditetapkan oleh pembeli dan penjual yang saling bernegosiasi. Penjual akan meminta harga lebih tinggi dari pada yang mereka harap akan mereka terima, dan pembeli akan menawar kurang dari apa yang mereka harap akan mereka bayar. Melalui tawar-menawar, mereka akhirnya akan sampai pada harga yang dapat diterima.

Dalam konsep Islam penentuan harga dilakukan oleh kekuatan pasar yaitu kekuatan permintaan dan penawaran. Pertemuan permintaan dengan penawaran tersebut haruslah terjadi secara rela sama rela, tidak ada pihak merasa terpaksa untuk melakukan transaksi pada suatu tingkat harga. Apabila para pedagang telah melakukan tindakan sewenangwenang dengan menaikkan harga hingga membahayakan keadaan pasar dan kepentingan umum, maka ketika itu wajiblah pemerintah turun tangan mençampuri urusan harga dengan menetapkan harga demi memelihara kepentingan orang banyak, mencegah penimbunan dan menghapuskan kedzaliman.

Begitu pula kebanyakan pemikir ḳontemporer juga menyetujui pendapat pemikir-pemikir dahulu, tetapi menambahkan atau mengelaborasinya ke dalam konteks modern. Al-Darimi dan An-Nabhani (dalam Rahman, 1995), misalnya, sangat mendukung kebijakan intervensi harga dalam situasi-situasi tertentu. Menurut Al-Darimi, kenaikan harga yang arbriter atau juga ketika para penjual demikian menguasai hukum dan pasar sehingga merugikan keadilan dan kepentingan masyarakat dapat menjadi alasan untuk intervensi harga. Karena menegakkan keadilan merupakan kewajiban syariah, maka intervensi. harga yang bertujuan untuk menegakkan keadilan juga menjadi kewäjiban. Logika didasarkan pada kaidah ushul fiqh: "maa laa yatimmu al wajib illa bihi fa huwa wajib" yang artinya segala sesuatu untuk pemenuhan suatu kewajiban juga menjadi kewajiban.

Dalam membahas pendapat Al-Darimi ini Al-Nabhani menambahkan, "Ketika para pedagang menjadi pemeras (exploiter) dan pendongkrak harga (jashi'in, mustaghillin) dan kepentingan (maślahah) masyarakat membutuhkan penerapan suatu kebijakan penetapan harga, dan hal ini menjadi kewajiban. Pemikir lain, Martan (Rahman, 1995), berpendapat bahwa kebijakan intervensi harga secara umum dapat dikenakan jika terdapat hal-hal yang menyebabkan kejahatan (sadd al dharaii), dalam konteks intervensi harga yang dikenakan pada barang-barang yang mubah dan berpotensi menimbulkan kejahatan. Tetapi, jika harga ditetapkan dalam situasi yang normal maka kenaikan harga dan distorsi harga justru akan merugikan masyarakat. Kebebasan pembeli dan penjual akan terhambat oleh harga yang ditetapkan tersebut. 
Jadi, dengan demikian Negara tidak perlu ragu-ragu untuk mengintervensi manakala ambang pintu keadilan terlewati dan tidak ada lagi justifikasi untuk menunggu kekuatan pasar memperbaiki pelanggaran tersebut dengan sendirinya. Namun juga perlu disadari intervensi itu sendiri tidak boleh semena-mena sebab bila hal tersebut terjadi, pada akhirnya juga akan menimbulkan ketidakadilan.

\section{DAFTAR PUSTAKA}

An-Nabhani, Taqiyudin (2000). Membangun Sistem Ekonomi Alternatif; Perspektif Islam. Surabaya: Risalah Gusti.

Chapra, M. Umar (2000). Sistem Moneter Islam, terjemahan Toward Just Monetary System, Jakarta: Gema Insani Press.

Chapra, M. Umer (2001). The Future of Economics: An Islamic Perspective. Jakarta: SEBI Institute.

Frank, Robert M. (2003). Micro Economics and Behavior. London: Routledge.

Islahi, Abdul Azim, (1996). Economic Concepts of Ibn Taimiyah. United Kingdom: The Islamic Foundation.

Karim, Adiwarman, (2002), Ekonomi Islam,Suatu kajian Kontemporer, Jakarta: Gema Insani Press.

Islahi, A.A, (1997). Konsep Ekonomi Ibnu Taimiyah (Diterjemahkan, oleh Anshari Thayib), Cet. I. Surabaya: PT. Bina Iman.

Mannan, M. Abdul (2001). Teori dan Praktek Ekonomi Islam. Yogyakarta: PT.Dana Bakti Wakaf.

Marthon, Said Sa'ad (2004). Ekonomi Islam di Tengah krisis Ekonomi Global. (Diterjemahkan oleh Ahmad Ikhrom dan Dimyauddin dari judul aslinya: al-Madkhal li al-Fikri al-lqtishaad fi al-Islam), Cetakan I. Jakarta: Zikrul Hakim.

Matrani, Muhammad Aidi (2008). Pemikiran Ibnu Taimiyyah tentang Mekanisme Pasar dalam Ekonomi Islam. Surakarta: Universitas Muhammadiyah

McKenzie, Richard B. (1983). The Limit of Economic Science. Kluwer: Nijhoft Publishing.

Mufraini, Arief (2006). Akuntansi dan Manajemen Zakat. Jakarta: Prenada.

Nasution, Mustafa Edwin (2007). Pengenalan Eksklusif Ekonomi Islam. Jakarta: Kencana.

Nu'man, Fikri Ahmad (1985). Annodzoriyah al-lqtishodiyah fi al Islam. Beirut: Maktabah Al Islami.

Partediredja, Ace (1999). Pengantar Ekonomika, Cet. VII. Yogyakarta: BPFE.

Siddiqi, Muhammad Nejatullah (1993). Muslim Economics Thinking: A Survey of Contemporary Literature. UK: Leiceister. 
Harga yang Adil Dalam Mekanisme Pasar (Mabarroh Azizah)

Sudarsono, Heri (2003). Konsep Ekonomi Islam, Suatu Pengantar. Cet. II. Yogyakarta: Ekonisia.

Ya'qub, Hamzah (2000). Kode Etika Dagang Menurut Islam, Pola Pembinaan Hidup dalam Berekonomi, Cet. 2. Bandung: CV. Diponegoro. 